\title{
PENGARUH PARTISIPASI DALAM PENGELOLAAN HUTAN NAGARI SIMANCUANG TERHADAP TINGKAT KESEJAHTERAAN MASYARAKAT
}

\author{
Community Participation in the Village Forest Management of Nagari \\ Simancuang and Its Impacts to Community Welfare
}

\author{
Xezly Fegis Zulevi ${ }^{1)}$ dan Soeryo Adiwibowo ${ }^{1)}$ \\ ${ }^{1)}$ Departemen Sains Komunikasi dan Pengembangan Masyarakat, Fakultas Ekologi Manusia, \\ Institut Pertanian Bogor, Dramaga Bogor 16680, Indonesia \\ Email: xezlyfegiszulevi95@gmail.com; s_adiwibowo@apps.ipb.ac.id
}

\begin{abstract}
The objective of this research is to analyse the impact of community participation in the village forest management of Simancuang to community welfare. A survey method to 30 respondents combined with qualitative data collection (in depth interviews) are applied in this study. The research located at the forest village Jorong Simancuang, Nagari Alam Pauh Duo, South Solok, West Sumatera. The results showed that the social forestry policy, which in this case protected forest Nagari Jorong Simancuang set as village forest, has generated community participation of Jorong in managing the village forest. Besides that, the result show that the social forestry policy and high participation of the Jorong Simancuang's community have had a significant impact in increasing household income, housing conditions, and respondent's residential environment of Jorong Simancuang.
\end{abstract}

Keywords: participation, social forestry policy, income, and housing conditions.

\begin{abstract}
ABSTRAK
Penelitian ini bertujuan untuk menganalisis pengaruh partisipasi dalam pengelolaan hutan nagari Simancuang terhadap tingkat kesejahteraan masyarakat. Penelitian ini menggunakan metode survei dengan 30 responden sebagai sumber data primer, dan dikombinasikan dengan pengumpulan data kualitatif. Lokasi penelitian ini dilaksanakan di Hutan Nagari Jorong Simancuang, Nagari Alam Pauh Duo, Solok Selatan, Sumatera Barat. Hasil penelitian ini menunjukkan bahwa kebijakan Perhutanan Sosial, yang dalam hal ini hutan lindung Nagari Jorong Simancuang ditetapkan sebagai Hutan Desa, telah membangkitkan partisipasi warga Jorong dalam mengelola hutan nagari. Selain itu, hasil penelitian ini juga menunjukkan kebijakan Perhutanan Sosial dan partisipasi tinggi warga Jorong Simancuang telah berpengaruh signifikan terhadap peningkatan pendapatan, kondisi rumah, dan lingkungan pemukiman responden Jorong Simancuang.
\end{abstract}

Kata Kunci: Perhutanan Sosial, partisipasi, pendapatan, dan kondisi rumah.

\section{PENDAHULUAN}

Penyelenggaraan pengelolaan sumberdaya hutan oleh Negara harus dilakukan secara optimal dan pemanfaatan sumberdaya hutan juga harus diimbangi dengan upaya pelestariannya, sehingga sumberdaya hutan dapat dimanfaatkan secara berkelanjutan untuk sebesar-besar kemakmuran rakyat. Hal ini sesuai dengan amanat UndangUndang Dasar 1945 pasal 33 ayat 3 yang berbunyi "Bumi dan air dan kekayaan yang terkandung di dalamnya dikuasai oleh Negara dan digunakan untuk sebesar-besar kemakmuran rakyat". Hal tersebut juga tertuang dalam Undang-undang Nomor 41 Tahun 1999 tentang Kehutanan, bahwa hutan merupakan kekayaan alam yang dianugerahkan oleh Tuhan kepada bangsa Indonesia, merupakan kekayaan yang dikuasai oleh Negara, memberikan manfaat serbaguna bagi umat manusia karenanya yang wajib disyukuri, dikelola dan dilestarikan sehingga dapat memberikan manfaat untuk sebesar-besar kemakmuran rakyat, bagi generasi sekarang maupun generasi mendatang. 
Salah satu langkah konkrit yang diambil pemerintah untuk memberdayakan masyarakat dalam mengelola hutan yang berada di wilayahnya yaitu dengan meluncurkan program Pengelolaan Hutan Berbasis Masyarakat (PHBM) dengan dasar hukum Peraturan Mentri Kehutanan Nomor 88 Tahun 2014 tentang Hutan Kemasyarakatan, Peraturan Menteri Kehutanan Nomor 89 Tahun 2014 tentang Hutan Desa. Inisiatif pengembangan hutan desa sebenarnya sudah berjalan sejak tahun 1999, bertepatan dengan disahkannya UU No. 41/1999 tentang Kehutanan. Inisiatif tersebut dihentikan karena pemerintah tidak dapat mengeluarkan perizinannya, dan sebagai kompromi dikembangkan Hutan Kemasyarakatan (HKm). Dengan pengembangan hutan desa diharapkan desa-desa hutan dapat membangun skema pendapatan asli desa untuk kesejahteraan masyarakat desa tersebut.

Hak akses desa terhadap hutan negara yang ada di dalam wilayahnya inilah yang kemudian diterjemahkan sebagai hutan desa. Pemberian akses ini dituangkan dalam Peraturan Menteri Kehutanan Nomor P.49/Menhut-II/2008, tentang Hutan Desa, yang ditetapkan pada tanggal 28 Agustus 2008. Peraturan ini kemudian diikuti dengan perubahan-perubahannya (Permenhut No. P.14/Menhut-II/2010 dan Permenhut No. P.53/Menhut-II/2011). Pada Hutan Desa, hak pengelolaan diberikan oleh Menteri Kehutanan/Pemerintah Daerah kepada lembaga desa dengan waktu 35 tahun dan dapat diperpanjang. Perizinan Hutan Desa dapat diberikan di areal hutan lindung atau produksi yang berada di dalam wilayah administrasi desa yang bersangkutan. Penetapan areal kerja hutan desa dilakukan oleh Menteri Kehutanan berdasarkan usulan Bupati/Walikota. Hak yang diberikan adalah hak pemanfaatan Hutan Desa bukan hak milik dengan status tetap di hutan negara.

Menurut Gunawan et.al (2012) pemahaman masyarakat desa hutan terhadap manfaat sumberdaya hutan, legalitas pengelolaan serta upaya pengamanan dan pelestarian merupakan bukti implementasi pengelolaan hutan untuk dapat meningkatkan kesejahteraannya yang diwujudkan dari beberapa gambaran pencapaian tujuan PHBM dalam bentuk kegiatan didalam kawasan hutan dan bagi hasil (sharing) pengelolaan hutan. Kegiatan budidaya pertanian dan usaha produktif di luar kawasan memberikan kontribusi terhadap peningkatan kesejahteraan masyarakat desa hutan. Selain itu, keberlansungan dalam pengelolaan hutan diatas dasari juga dengan didirikannya lembaga pengelolaan hutan desa (LPHD). Peran LPHD bertugas dalam pelaksanaan semua program pengelolaan hutan. Adapun menurut ostrom (1990) Kelembagaan yang baik dan efektif akan menjamin keberlanjutan pemanfaatan dan pengelolaan sumber daya alam. Berbagai kajian kelembagaan lokal telah menunjukkan bahwa keberhasilan pengelolaan hutan oleh masyarakat tidak dapat dilepaskan dari kekuatan nilai dan norma yang telah mengakar dan diterima secara luas oleh masyarakat.

Hubungan manusia dan hutan dapat membentuk perilaku masyarakat yang lebih peduli terhadap kelestarian hutan. Pada penelitian ini merujuk pada masyarakat Jorong Simancuang Kenagarian Alam Pauh Duo Kecamatan Pauh Duo Kabupaten Solok Selatan di Sumatera Barat, dengan terdapatnya keberadaan hutan nagari yang lestari menimbulkan pemahaman dalam melindungi hutan. Oleh sebab itu, kawasan hutan Jorong Simancuang ditetapkan oleh Keputusan Menteri Kehutanan SK. 573/Menhut-II/2011 menjadi penetapan kawasan hutan lindung sebagai areal kerja hutan desa/nagari. Semenjak ditetapkan menjadi kawasan Hutan Desa (HD) atau Hutan Nagari (HN) perlunya lembaga dalam mengelolaa hutan nagari tersebut. Terdapatnya Lembaga Pengelolaan Hutan Nagari (LPHN) akan dapat membantu keberlangsungan aktivitas sosial ekonomi mereka. Dengan terdapatnya LPHN munculah partisipasi masyarakat dalam mengikuti program dan kegiatan pengelolaan hutan.

Masalah Penelitian dirumuskan sebagai berikut:

1. Bagaimana pengaruh dari kebijakan akses dan program pengelolaan hutan desa terhadap partisipasi warga Jorong Simancuang dalam pengelolaan hutan?

2. Bagaimana pengaruh dari partisipasi warga Jorong Simancuang, Nagari Alam Pauh Duo, Kabupaten Solok Selatan, dalam pengelolaan 
hutan nagari terhadap tingkat kesejahteraan warga Jorong Simancuang?

\section{PENDEKATAN TEORITIS}

\section{Perhutanan Sosial}

Hutan adalah suatu kesatuan ekosistem berupa hamparan lahan berisi sumber daya alam hayati yang didominasi pepohonan dalam persekutuan alam lingkungannya, yang satu dengan lainnya tidak dapat dipisahkan (UU No.41 Tahun 1999, Pasal 1). Hutan dapat diartikan sebagai kumpulan pepohonan yang tumbuh rapat beserta tumbuhtumbuhan memanjat disertai bunga yang beraneka warna yang memiliki peran sangat penting untuk kehidupan masyarakat. Sesuai UU Nomor 41 Tahun 1999, kawasan hutan adalah wilayah tertentu yang ditunjuk dan ditetapkan oleh pemerintah untuk dipertahankan keberadaannya sebagai hutan tetap. Oleh sebab itu, hutan memang wajib dijaga demi keberlangsungan kehidupan generasi-generasi mendatang.

Peraturan Menteri LHK No. P.83/MENLHK/SETJEN/KUM.1/10/2016

Tentang Perhutanan Sosial Bab 1, Pasal 1 yang dimaksut dengan perhutanan sosial adalah sistem pengelolaan hutan lestari yang dilaksanakan dalam kawasan hutan negara atau hutan hak/ hutan adat yang dilaksanakan oleh masyarakat setempat, atau masyarakat hukum adat sebagai pelaku utama untuk meningkatkan kesejahteraan, keseimbangan lingkungan dan dinamika sosial budaya dalam bentuk Hutan Desa, Hutan Kemasyarakatan, Hutan Tanaman Rakyat, Hutan Rakyat, Hutan Adat dan Hutan Kemitraan. Selain itu adanya prinsip dalam pengelolaan perhutanan sosial yang terdapat pada Pasal 3, tentang Pengelolaan Perhutanan Sosial yang memperhatikan prinsip : (1). keadilan, (2). keberlanjutan (3). kepastian hukum (4). Partisipatif, dan (5). Bertanggung Gugat.

\section{Hutan Desa}

$\begin{array}{lll}\text { Peraturan Menteri LHK No. } & \end{array}$ P.83/MENLHK/SETJEN/KUM.1/10/2016

Tentang Perhutanan Sosial pada Bab 1, Pasal 1 mengenai Hutan Desa yang termasuk dalam kawasan hutan negara dan kemudian dikelola oleh desa, serta dapat dimanfaatkan untuk kesejahteraan masyarakat. Adapun pada skema hutan desa terdapatnya Hak Pengelolan Hutan Desa (HPHD) dalam pengelolaan pada kawasan hutan lindung atau hutan produksi yang diberikan lansung kepada lembaga desa. Peran Lembaga Pengelolaan Hutan Desa (LPHD) adalah sebagai lembaga kemasyarakatan desa yang bertugas untuk mengelola Hutan Desa.

Berdasarkan Peraturan Menteri LHK No. P.83/MENLHK/SETJEN/KUM.1/10/2016

tentang pedoman penyusunan Rencana Pengelolaan Hutan Desa (RPHD), yang terdapat didalamnya rencana kerja usaha, izin usaha pemanfaatan hutan kemasyarakatan dan rencana kerja usaha izin usaha pemanfaatan hasil hutan kayu tanaman rakyat, pada Pasal 4 tentang penyusunan RPHD berdasarkan peta areal kerja yang meliputi kegiatan:

a. penandaan batas

b. pembagian blok atau zonasi

c. pengelolaan atau pemanfaatan

d. monitoring, pelaporan dan evaluasi

Pada penyusunan RPHD terdapatnya penandaan batas dan pembagian blok atau zonasi sebagaimana dimaksud dalam Pasal 4 terdiri dari: blok atau zonasi konservasi atau lindung dengan memperhatikan sepandan sungai, pantai, danau, dan mata air dan blok atau zona pemanfaatan.

\section{Tingkat Partisipasi Masyarakat}

Menurut penelitian Hidayah (2012) pengelolaan hutan bersama masyarakat memiliki rangkaian program-program yang melibatkan masyarakat dalam pelaksanaan pengelolaan hutan. Program dimaksud mengandung azaz kemitraan dan memiliki prisnip untuk menyelaraskan kepentingan antara setiap pemangku kepentingan (stakeholders). Adapun menurut Cohen dan Adapun menurut Soelaiman (1985) dalam Theresia (2008), partisipasi anggota masyarakat dalam kegiatan pembangunan adalah sikap mendukung dan terlibatnya masyarakat baik secara individu maupun kelompok atau ke dalam kesatuan bersama untuk merencanakan dan melaksanakan, atas dasar tanggung jawab sosial. Yadov (1980) dalam Theresia (2008) empat macam partisipasi masyarakat dalam pembangunan yaitu: 
1. Partisipasi dalam pembuatan perencanaan dan partisipasi dalam pengambilan keputusan

2. Partisipasi dalam pelaksanaan kegiatan

3.Partisipasi dalam pemanfaatan hasil
pembangunan

4. Partisipasi dalam pemantauan dan evaluasi.

\section{Tingkat Kesejahteraan Masyarakat}

Kesejahteraan dapat dilihat dari beberapa ruang lingkup. Ruang lingkup yang dapat dijadikan pedoman dalam mengukur kesejahteraan adalah dari aspek ekonomi, sosial, dan psikologi seperti yang dijelaskan pada penelitian Sunarti (2006). Kesejahteraan ekonomi dapat diartikan sebagai kondisi dimana secara financial pendapatan- nilai asset keluarga, maupun pengeluaran telah terpenuhi dan diterimanya manfaat langsung dari terpenuhinya hal-hal tersebut. kesejahteraan sosial meliputi beberapa komponen seperti dukungan sosial dan penghargaan (self esteem) yang dapat memaksimalkan kinerja dari pengembagan manusia. Untuk kesejahteraan psikologi dapat dikatakan sebagai keterkaitan anatara emosi dan hal-hal yang menjadi kepuasan dalam hidup. Aspek-aspek yang berhubungan dengan kesejahteraan psikologi atara lain kecemasan, depresi, harga diri, konsep diri, dan suasana hati. Berdasarkan Hasil Pencacahan Survei Kehutanan Rakyat (2010), variabel kesejahteraan rumah tangga yang bermukim di kawasan hutan, antara lain meliputi:

1. Pendapatan rumah tangga

2. Kondisi perumahan dan lingkungan

\section{Kerangka Pemikiran}

Adanya pengelolaan hutan desa dan partisipasi masyarakat dalam kebijakan akses dan program pengelolaan hutan yang telah ditetapkan perhutanan sosial diharapkan mampu memberikan perubahan bagi masyarakat. Dengan dibentuknya LPHD sebagai lembaga yang memiliki peran dalam pelaksanaan pengelolaan hutan dengan melaksanakan kegiatan serta program-program yang telah di rancang dalam RPHD. Oleh sebab itu, dengan terdapatnya dukungan serta kebijakan dari pemerintah tentang aturan dalam pengelolaan hutan, masyarakat kini dapat akses dan berparisipasi dalam pengelolaan hutan sesuai dengan ketentuan yang telah di tetapkan.

Selanjutnya, dengan terdapatnya kebijakan akses dan program pengelolaan hutan yang sudah di tetapkan oleh peraturan Menteri Lingkungan Hidup dan Kehutanan dalam pengelolaan hutan desa, serta dengan dilibatkannya masyarakat dalam berpartisipasi pada sistem perencanaan, pelaksanaan, pemanfaatan dan evaluasi, menunjukkan terjadinya efektivitas program pengelolaan hutan desa tersebut. Adapun pada suatu perencanaan masyarakat dilibatkan dalam hal memberikan pendapat dalam membangun program pengelolaan hutan desa agar menjadi lebih baik. Selain itu, dalam pelaksanaan, masyarakat bekerjasama dengan LPHD dan pemerintah daerah dalam pelaksanaan pengelolaan hutan tersebut. Sedangkan pada tahap pemanfaatan, masyarakat diharapkan dapat mempergunakan hasil hutan dengan aturan dan ketentuan yang telah ditetapkan dalam pengelolaan hutan desa, agar dapat membantu dalam meningkatkan pendapatan masyarakat tersebut. Oleh sebab itu, dengan adanya pengelolaan hutan desa juga dapat memberikan pengaruh terhadap kesejahteraan masyarakat desa dengan terpenuhinya kebutuhan material, spiritual, dan sosial masyarakat desa agar dapat hidup layak dan mampu mengembangkan dirinya. Dengan itu, untuk mengukur adanya kebijakan akses dan program pengelolaan hutan desa, serta berdampaknya terhadap tingkat kesejahteraan masyarakat yang tinggal dikawasan hutan, dapat dilihat melalui kondisi hasil pendapatan rumah tangga petani dan kondisi perumahan dan lingkungan. Dari tahap yang telah dilakukan, dengan adanya kebijakan akses dan program pengelolaan hutan desa, dapat menjadi program pemberdayaan yang lebih baik lagi. Maka dengan tahap evaluasilah menjadi hal yang penting dalam program tersebut. Oleh sebab itu, kerangka pemikiran yang muncul ialah melihat pengaruh partisipasi masyarakat dalam peraturan pengelolaan hutan desa tahun 2016 yaitu kebijakan akses dan program pengelolaan Hutan Desa, dan rencana pengelolaan hutan desa terhadap tingkat kesejahteraan masyarakat Desa hutan.

(X1) Peraturan Perhutanan Sosial (2016) Hutan Desa

(X1.1) Kebijakan Akses (hak) dan Program Pengelolaan Hutan Desa

(X1.2) Rencana Pengelolaan Hutan Desa (RPHD) 


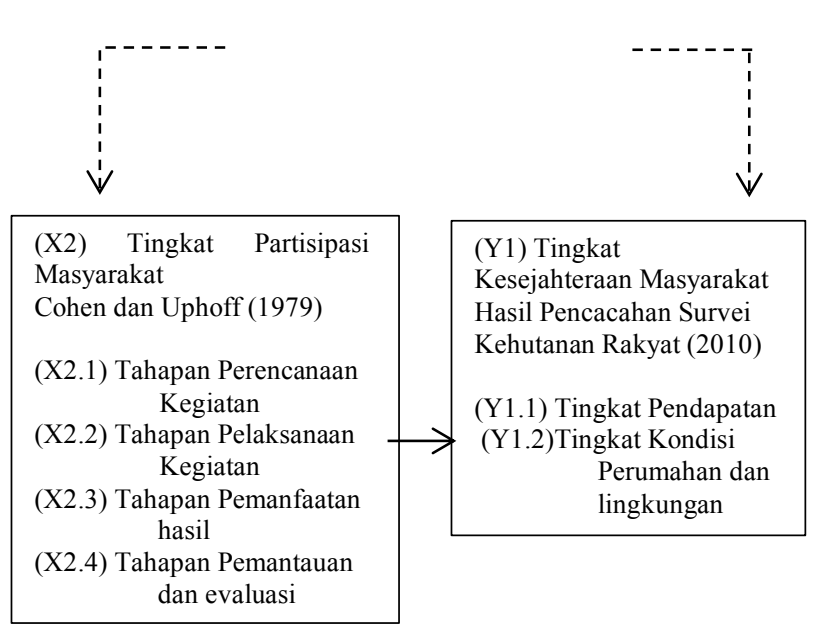

\section{Gambar 1 Kerangka pemikiran}

\section{Hipotesis}

Berdasarkan kerangka pemikiran di atas, maka dirumuskan hipotesis dari penelitian ini yaitu:

1. Kebijakan Perhutanan Sosial (khususnya Hutan Desa) telah menjadi pendorong meningkatnya partisipasi masyarakat dalam pengelolaan hutan nagari Jorong Simancuang.

2. Tingkat pendapatan dan kualitas perumahan dan lingkungan warga meningkat sebagai akibat dari meningkatnya partisipasi masyarakat dalam pengelolaan hutan nagari Jorong Simancuang.

\section{PENDEKATAN LAPANG}

Penelitian ini merupakan penelitian survei yang digunakan untuk maksud penjelasan atau disebut dengan explanatory. Dalam penelitian explanatory memberikan atas suatu fenomena yang dianalisis. Hubungan antar variable dengan maksud untuk menguji teori atau hipotesis yang dijadikan (Singarimbun dan Effendi 2012). Penelitian survei menganalisis salah satu bentuk atau tipe penelitian kuantitatif. Penelitian ini merupakan penelitian kuantitatif yang dalam analisis datanya dikombinasikan dengan pengelolaan data kuanlitatif. Metode yang digunakan dalam penelitian ini adalah metode survei yang dilakukan dengan pemberian kuesioner terstruktur dan wawancara mendalam kepada responden. Instrumen penting yang digunakan dalam penelitian survei ini adalah kusioner terstruktur pada sejumlah responden, dan wawancara masalah kepada beberapa informan. Selain memperoleh data primer secara langsung kepada responden dan informan di lokasi penelitian, data sekunder juga dikumpulkan seperti data publikasi BPS, jurnaljurnal penelitian terdahulu, dan juga buku rujukan.

Penelitian dilaksanakan di Hutan Nagari di Jorong Simancuang Nagari Alam Pauh Duo, Kecamatan Pauh Duo, Kabupaten Solok Selatan, Sumatra Barat. Pemilihan lokasi penelitian dilakukan secara sengaja (purposive). Dari kacamata hukum positif, kawasan hutan nagari ini merupakan kawasan hutan negara yang berfungsi lindung. Baru enam tahun silam pemerintah menetapkan kawasan hutan nagari Jorong Simancuang ini sebagai Hutan Desa yang dikelola dengan prinsip Perhutanan Sosial. Dengan adanya perubahan tata kelola ini warga masyarakat sekarang dapat mengakses secara legal sumber daya hutan Jorong Simancuang dengan mengindahkan ketentuan-ketentuan yang digariskan.

Kegiatan penelitian ini dilaksanakan dalam waktu lima bulan, mulai bulan Januari 2017 sampai dengan Agustus 2017. Kegiatan penelitian menempuh tahapan penyusunan proposal penelitian, uji petik proposal penelitian, kolokium, perbaikan proposal penelitian, pengambilan data lapang, pengolahan dan analisis data lapang, penyusunan skripsi, uji kelayakan, sidang skripsi dan perbaikan skripsi.

Dalam penelitian ini data primer digali dari responden dan informan. Informan adalah individu (umumnya tokoh) yang dapat memberikan informasi dan data sebanyak mungkin tentang situasi dan kondisi sosial, ekonomi, budaya dan lingkungan hidup diluar bersangkutan yang terkait dengan tujuan studi ini. Adapun responden adalah individu yang memberikan informasi dan data tentang kondisi sosial dan ekonomi dari individu dan rumah tangga individu bersangkutan. Populasi dalam penelitian ini adalah warga Jorong Simancuang, Nagari Alam Pauh Duo, Kecamatan Pauh Duo, Kabupaten Solok Selatan, Sumatera Barat. 
Pemilihan responden dilakukan melalui metode pengambilan sampel acak sederhana (simple random sampling), dengan syarat masyarakat asli tinggal di Jorong Simancuang atau petani yang terlibat dalam pengelolaan hutan. Responden yang diambil berjumlah 30 orang dari 112 populasi berdasarkan asumsi bahwa populasi yang diambil memiliki sebaran normal. Selain itu, informasi diperoleh juga dari para informan yang mewakili Kementerian Lingkungn Hidup dan Kehutanan, Dinas Kehutanan Provinsi Sumatra Barat, Kepala Lembaga Pengelolaan Hutan Nagari (LPHN) Jorong Simancuang, KKI Warsi sebagai LSM pendamping dan melakukan wawancara mendalam dengan masyarakat setempat.

Data yang dikumpulkan dalam penelitian ini meliputi data primer dan data sekunder. Teknik pengumpulan data yang dilakukan menyesuaikan dengan jenis datanya. Data primer diperoleh secara langsung dengan menggunakan teknik survei di lokasi penelitian dan menggunakan instrumen kuesioner, wawancara mendalam berdasarkan panduan pertanyaan dengan responden dan informan, serta observasi. Data sekunder diperoleh dari dokumen-dokumen catatan kantor pemerintahan, buku, internet, serta jurnal-jurnal penelitian terkait.

Dara primer diperoleh dari hasil kuesioner dari responden dan wawancara mendalam kepada informan (Lampiran 3). Kuesioner akan diujikan terlebih dahulu kepada 10 responden rumahtangga di luar dari target rumahtangga yang akan diteliti. Pengujian kuesioner dilakukan di Jorong Simancuang. Pengujian kuesioner dimaksudkan untuk menguji validitas dan realibilitas kuesioner yang merupakan instrumen pengumpulan data kuantitatif. Pengisian kuisioner dipandu oleh peneliti untuk mencegah terjadinya kesalahan dalam pengisian jawaban.

Penelitian ini menggunakan jenis data kuantitatif yang diolah menggunakan aplikasi Microsoft Excell 2010 dan SPSS. for windows 23.0 kemudian dianalisis menggunakan crosstabs. Pembuatan tabel frekuensi, diagram, serta tabel tabulasi silang untuk melihat data awal responden untuk masing-masing variabel secara tunggal menggunakan aplikasi Microsoft Excell 2010. Kemudian SPSS. for windows 23.0 digunakan untuk membantu dalam uji statitistik yang akan menggunakan tabulasi silang. Tabulasi silang merupakan cara pengolahan data untuk mengetahui pengaruh variabel tergantung dengan variabel bebas.

Data kualitatif merupakan data pendukung yang diolah dan dianalisis dengan konten analisis. Pengolahan dan analisis data kualitatif dilakukan dengan mereduksi atau meringkas data dengan menggolongkan, mengarahkan, membuang yang tidak perlu dan mengorganisasikan data sedemikian rupa sehingga sesuai dengan keperluan untuk menjawab pertanyaan analisis di dalam penelitian. Selanjutnya dilakukan penyajian data dengan menyusun data dan informasi yang diperoleh dalam bentuk matriks dan narasi sehingga mudah dipahami. Verifikasi adalah langkah terakhir yang merupakan penarikan kesimpulan dari hasil yang telah diolah pada tahap reduksi.

\section{HASIL DAN PEMBAHASAN}

\section{Gambaran Umum Lokasi Penelitian}

Hutan Nagari Jorong Simancuang merupakan salah satu wilayah Nagari Alam Pauh Duo, Kecamatan Pauh Duo, Kabupaten Solok Selatan, Sumatera Barat. Tepatnya terletak pada $101^{0} 7^{\prime}$ 9,73'" s/d $101^{0}$ 9' 27,57" BT $1^{0} 31$ ' 12,16" s/d $1^{0}$ 33' 33,26" BT; dengan jarak dari pusat Kabupaten $\pm 10 \mathrm{~km}$ dan $\pm 200 \mathrm{~km}$ jarak dari Ibu Kota Provinsi. Luas areal hutan nagari Simancuang 568 ha. Sungai yang mengalir ke pemukiman masyarakat berasal dari Batang Hari hulu hutan nagari Jorong Simancuang berjarak sekitar 200 meter dari pemukiman terdekat dan memiliki kemiringan sekitar $80 \%$. penduduk.

Sebagian besar lahan di Jorong Simancuang didominasi oleh pertanian/perkebunan 297 hektar (45,54 persen) dan hutan sekunder 267 hektar (41,08 persen) lahan pertanian/perkebunan dipergunakan sebagai mata pencaharian dari masayarkat Jorong Simancuang, Adapun lahan hutan sekunder adalah kawasan hutan nagari simancuang.

Infrastruktur yang ada disekitar Jorong Simancuang belum cukup memadai, dengan tidak adanya akses kendaraan umum untuk menuju 
Jorong Simancuang. Selain itu kondisi jalan masih berbatuan dan terdapat tebing curam di sepanjang jalan. Fasilitas umum dan fasilitas sosial yang terdapat di Jorong Simancuang meliputi Sekolah Menengah Pertama (SMP) dan Sekolah Dasar (SD). Namun tidak terdapat Sekolah Menengah Atas (SMA) dan perguruan tinggi.

Menurut data profil Jorong Simancuang tahun 2012 yang didapatkan dari kecamatan Alam Pauh Duo terdapat 718 jiwa jumlah penduduk. Dari total keseluruhan tersebut terdapat 2 jorong, yaitu Jorong Simancuang dan Jorong Simancuang Karang Hitam. Dari total jumlah penduduk yang ada, berikut perbandingan proposisi antara lakilaki dan perempuan di Jorong Simancuang. Berdasarkan data tersebut dapat dilihat jumlah penduduk laki-laki lebih banyak dibandingkan jumlah penduduk perempuan, ditunjukkan dengan jumlah rasio perbandingan antara jumlah penduduk laki-laki dan perempuan 1,06.

Jorong Simancuang merupakan daerah yang terdapat disekitar kawasan hutan lindung dengan mayoritas pekerjaannya adalah sebagai petani. Adapun penghasilan yang mereka dapati sepenuhnya dari hasil pertanian sawah. Setiap masyarakat Jorong Simancuang yang memiliki pertanian sawah, ikut serta dalam mengelolah pertanian pertanian sawah tersebut secara bersama-bersama saat kondisi menanan hingga hasil panen. Sehingga sebagian besar masyarakat di Jorong Simancuang menggantungkannya kehidupannya dengan hasil pertanian.

Adapun mata pencaharian masyarakat Jorong Simancuang terdapat persentase dengan mata pencaharian petani adalah yang terbesar. Selanjutnya diposisi bawahnya, terdapat masyarakat dengan mata pencaharian sebagai PNS. Hal tersebut dilihat dari kondisi Jorong Simancuang yang merupakan wilayah terpencil dan masyarakat hanya dapat memanfaatkan penghasilan dari pertanian yaitu tanaman sawah dan hasil pertanian lainnya.

Tingkat pendidikan responden diukur berdasarkan tingkat pendidikan formal yang pernah diikuti oleh responden. Berdasarkan data yang ditemui di lapang, maka tingkat pendidikan responden digolongkan menjadi tiga tingkatan, yaitu responden dengan tingkat pendidikan menamatkan SD/sederajat, responden dengan tingkat pendidikan tamat SMP/ sederajat dan responden dengan tingkat pendidikan sekolah menegah atas (SMA). Adapun terdapatnya lebih dari setengah warga yang menjadi responden adalah masyarakat Jorong Simancuang yang memiliki tingkat pendidikan rendah, yaitu hanya sampai dengan sekolah dasar (SD) .

Adapun pada kondisi lama tinggal responden terdapatnya, mayoritas responden tersebut tinggal sudah 18 tahun sampai dengan 29 tahun di Jorong Simancuang. Hal tersdebut dapat dikatakan bahwa terbilang cukup lama. Selain itu, diketahui juga masyarakat yang tinggal di Jorong simacuang bukan masyarakat asli sejak dari Jorong Simancuang itu sendiri, melainkan masyarakat rantauan dari jorong lain ataupun dari daerah lainnya.

\section{Sejarah Terbentuknya Hutan Nagari Simancuang}

Ditinjau dari perspektif hukum positif (yakni berdasarkan peraturan perundangan yang diterbitkan oleh negara) hutan Nagari Jorong Simancuang tergolong sebagai hutan yang dikuasai oleh negara dengan fungsi sebagai Hutan Lindung. Status dan fungsi hutan ini masih berlaku hingga saat ini. Namun demikian sejak masa kemerdekaan hingga sekarang hutan Nagari Jorong Simancuang secara de-facto masih dikelola oleh warga Nagari Simacuang.

Mengingat negara (dalam hal ini) Pemerintah Daerah setempat tidak mampu melakukan penegakan hukum terhadap batas dan isi yang terkandung dalam Hutan Lindung Simancuang; maka timbul fenomena akses terbuka (open access) terhadap sumber daya hutan Simancuang. Terjadi penebangan liar yang dilakukan oleh warga jorong lain yang menyebabkan longsor dan turunnya volume air sungai ke Jorong Simancuang. Warga tidak dapat melakukan penindakan terhadap pelaku karena kawasan hutan Simancuang secara juridis bukan lagi menjadi milik warga Simancuang.

Keluarnya penetapan areal kerja hutan desa/nagari Jorong Simancuang oleh Menteri Kehutanan seluas 650 ha, sesuai dengan Peraturan Menteri Kehutanan Nomor 
P.49/Menhut-II/2008 tentang Hutan Desa, yang selanjutnya ditindaklanjuti dengan penerbitan Hak Pengelolaan Hutan Nagari dari Gubernur Sumatera Barat dengan keputusan Nomor 52243-1012 tanggal 19 Januari 2012. Berkat keluarnya ketetapan Menteri Kehutanan dan Gubernur Sumatera Barat atas HPHD hutan nagari simancuang, sebagai langkah awal yang baik untuk segera mewujudkan pengelolaan hutan yang lebih baik dan segera dapat mewujudkan pengelolaan hutan yang lebih baik. Oleh sebab itu, masyarakat Jorong Simancuang sudah dapat memulai mengelola hutan sesuai dengan aturan yang telah dikeluarkan. Adapun sebelum memulai untuk pengelolaan hutan nagari tersebut, perlunya disusun rencana kelola hutan desa/nagari sebagai bentuk komitmen masyarakat Jorong Simancuang dan nagari dalam mengelola hutan yang telah ditetapkan. Adapun sebelum memulai penyusunan RPHN, melalui ketetapan pengelolaan hutan dengan perlu dibentuknya suatu lembaga untuk menaugi pengelolaan hutan tersebut. Oleh sebab itu, dengan bantuan dari beberapa pihak terkait seperti KKI warsi dalam pembentukan kelembagaan serta rancangan dalam pengelolaan hutan nagari.

\section{Kebijakan Pengelolaan Dan Rencana Pengelolaan Hutan Nagari (Rphn)}

\section{Kebijakan Akses dan Pengelolaan Hutan Nagari}

Peraturan Menteri LHK

\section{No.P.83/MENLHK/SETJEN/KUM.1/10/2016}

tentang Perhutanan Sosial dalam Pemanfaatan Areal Perhutanan Sosial Pasal 51, terdapatnya HPHD pada pemanfaatan hutan lindung berupa, pemanfaatan kawasan, pemanfaatan jasa lingkungan dan pemanfaatan pemungutan hasil hutan bukan kayu. Adapun selain itu, mengenai Hak dan Kewajibab pada Pasal 58, terdapatnya perlindungan dari gangguan perusahaan dan pencemaran lingkungan atau pengambilan secara sepihak oleh pihak lain dalam mengelola dan memanfaatkan HPHD sesuai dengan kearifan lokal, yaitu dengan sistem usaha tani terpadu, dapat mengembangkan ekonomi produktif berbasis kehutanan, selain itu mendapat pendampingan dalam pengelolaan $\mathrm{HD}$, serta mendapat pendampingan kemitraan dalam pengembangan usaha hasil pertanian ataupun hasil hutan. Oleh sebab itu, harapannya dengan adanya pentapan dalam HPHD dapat berjalan dengan secara lancar dan sesuai dengan peraturan yang telah ditetapkan.

\section{Rencana Pengelolaan Hutan Nagari}

Berdasarkan Peraturan Menteri LHK No. P.83/MENLHK/SETJEN/KUM.1/10/2016 tentang Perhutanan Sosial dalam rencana pengelolaan hutan desa dan rencana kerja usaha yang dimaksut pada ayat (1) dan ayat (2) telah disahkan oleh penyuluh dalam hal areal kerja HPHD berada dalam satu desa/nagari, yang terdiri dari kepala pengelolaan hutan (KPH) yang sudah operasional, atau kepala berdasarkan rencana pengelolaan hutan jangka panjang $\mathrm{KPH}$ setempat bagi areal kerja HPHD, serta kepala dinas Provinsi dalam HPHD berada di lintas desa dan belum ada KPH operasional.

Sejauh mana warga Jorong Simancuang mengetahui dan memahami kebijakan akses yang baru dalam hak pengelolaan hutan desa. Terdapat 93,3 persen masyarakat Jorong Simancuang dapat mengambil kayu dari dalam hutan. Hal tersebut dikarenakan sudah diberlakukannya kebijakan atas hak dan pengelolaan hutan secara resmi. Adapaun kayu yang diambil masyarakat Jorong Simancuang, bukan kayu yang untuk dikomersilkan, melainkan dipergunakan sebagai kebutuhan rumah tangga seperti kayu bakar. Sedangkan terdapat 73,3 persen masyarakat Jorong Simancuang dapat mengambil hasil pertanian dari lahan garapan pertanian yang sudah ada sejak dahulunya, seperti kopi, karet, pinang, kayu manis dari dalam kawasan hutan nagari, adapun lahan yang terdapat didalam kawasan hutan nagari tersebut berguna sebagai hasil pertanian tambahan penghidupan masyarakat selain dari hasil pertanian sawah. Sedangkan untuk pakan ternak sendiri masyarakat Jorong Simancuang dengan 100 persen dapat mengambil dari dalam hutan, namun kebanyakan masyarakat Jorong Simancuang tidak ada yang mengambil dari dalam hutan melainkan hanyalah pakan dari tanaman yang berada di sekitar pemukiman masyarakat.

Selain itu, pada kebijakan pengelolaan hutan, terdapatnya 90 persen mengatakan bahwa dapat mempergunakan air dari dalam hutan sebagai 
kebutuhan sehari-hari, adapun air yang dipergunakan dari dalam hutan adalah untuk air mandi dan air minum. Selanjutnya terdapatnya 100 persen masyarakat Jorong Simancuang mempergunakan aliran air dari hutan nagari untuk kebutuhan irigasi pertanian. Berdasarkan responden dengan sebanyak 100 persen menyatakan bahwa yang melanggar peraturan tersebut mendapatkan sanksi, yaitu berupa dari hukum adat dan ketetapan bersama LPHN dalam menangani pelanggaran peraturan pengelolaan Hutan Nagari. Adapun yang melanggar perturan dalam hak pengelolaan hutan nagari tersebut, yaitu dengan menebang hutan secara liar. Namun yang melanggar tersebut bukanlah dari masyarakat Jorong Simancuang itu sendiri, melainkan warga dari luar yang mengambil kayu. Selain itu, terdapatnya 96,7 persen peran pemerintah dalam memberikan akses dan pengelolaan hutan sudah sangat baik yaitu dengan banyaknya kegiatan - kegiatan pemberdayaan dan program yang diberikan dalam mengelolaa Hutan Nagari.

Berdasarkan pada Tabel 1, terdapatnya pandangan terhadap program pengelolaan hutan nagari Simancuang, dengan 83,3 persen masyarakat sudah mendapatakan pendampingan pengelolaan hasi hutan nagari. Namun, masih belum terdapatnya keberlanjutan hingga saat ini dalam pengelolaan hasil hutan tersebut. Sedangkan pada pendampingan kemitraan dalam pengelolaan hasil hutan di lihat dari 20 persen menyatakan bahwa sudah mulai adanya hubungan kemitraan dalam pengelolaan hasil Hutan Nagari.

Selain itu, terdapat satu (1) responden yang mulai membuat industri rumah tangga dari hasil hutan (rotan). Adapun 96,7 persen responden menyatakan telah menerima pelatihan perlindungan terhadap kerusakan dan pencemaran lingkungan.

Tabel 1 Jumlah dan persentase responden menurut pandangan terhadap program pengelolaan hutan nagari Simancuang

\begin{tabular}{lcccccc}
\hline \multirow{2}{*}{ Jawaban } & \multicolumn{2}{c}{ Ya } & \multicolumn{2}{c}{ Tidak } & \multicolumn{2}{c}{ Total } \\
\cline { 2 - 7 } & $\mathrm{n}$ & $\%$ & $\mathrm{n}$ & $\%$ & $\mathrm{n}$ & $\%$ \\
$\begin{array}{l}\text { Mendapat } \\
\text { pendampingan } \\
\text { dalam }\end{array}$ & 25 & 83,3 & 5 & 16,7 & 30 & 100 \\
\hline
\end{tabular}

pengelolaan

hasil hutan

Terdapat

pendampingan

$\begin{array}{lllllll}\text { kemitraan dalam } & 6 & 20 & 24 & 80 & 30 & 100\end{array}$

pengembangan

usaha hasil hutan

Membuat

industri rumah

tangga dari hasil

hutan

Terdapat

pelatihan dalam

perlindungan

perusakan dan

$\begin{array}{llllll}29 & \mathbf{9 6 , 7} & 1 & 3,3 & 30 & 100\end{array}$

pencemaran

lingkungan

\section{Pengaruh Kebijakan Pengelolaan Hutan Nagari terhadap Tingkat Kesejahteraan Masyarakat Jorong Simancuang}

Berdasarkan kebijakan yang ditetapkan oleh peraturan Menteri Lingkungan Hidup dan Kehutanan

No.P.83/MENLHK/SETJEN/KUM.1/10/2016

tentang Perhutanan Sosial, dengan terdapatnya HPHD dalam pengelolaan hutan desa memberi peluang bagi masyarakat ikut serta dalam pengelolaan hutan tersebut. Adapun sistem dalam pengelolaan hutan nagari tersebut di berikan lansung kepada pihak LPHN untuk melaksanakan kegiatan pengelolaan hutan. Terdapat dengan diberikannya ketetapan peraturan dalam pengelolaan hutan nagari simancuang, masayarakatpun ikut andil dalam proses awal pembentukan hingga pelaksanaan program pengelolaan hutan nagari. Hal tersebut dapat dilihat pada proses partisipasi masyarakat dalam pengelolaan hutan nagari yang terdapat dalam tahapan-tahapan pada saat awal pembentukan hutan simancuang menjadi kawasan hutan desa hingga sampai saat ini. Berdasarkan Tabel 2, terdapatnya tahapan perencanaan pada saat pembentukan awal dari program pengelolaan hutan nagari simancuang dengan skor rata-rata 3,75 bahwa masyarakat Jorong Simancuang sering mengikuti perkumpulan kampung pada saat awal perencanaan program dalam pengelolaan hutan nagari. Sedangkan pada tahapan pelaksanaan kegiatan dengan skor ratarata 3,73 masyarakat Jorong Simancuang juga 
sering terlibat dalam pelaksanaan kegiatan pengeloaan hutan nagari.

Tabel 2 Skor rata-rata tahapan partisipasi masyarakat Jorong Simancuang

\begin{tabular}{clc}
\hline No. & \multicolumn{1}{c}{ Tahapan Partisipasi } & $\begin{array}{c}\text { Skor Rata- } \\
\text { rata }\end{array}$ \\
\hline 1. & $\begin{array}{l}\text { Tahapan perencanaan } \\
\text { kegiatan }\end{array}$ & 3,75 \\
2. & $\begin{array}{l}\text { Tahapan pelaksanaan } \\
\text { kegiatan }\end{array}$ & 3,73 \\
3. & $\begin{array}{l}\text { Tahapan pemanfaatan hasil } \\
\text { kegiatan }\end{array}$ & 3,95 \\
4. $\begin{array}{l}\text { Tahapan pemantauan dan } \\
\text { evaluasi kegiatan }\end{array}$ & 3,5 \\
\hline
\end{tabular}

Adapun pada tahapan pemanfataan hasil kegiatan dengan skor rata-rata 3,95 masyarakat Jorong Simancuang juga sering terlibat ikut dalam kegiatan tersebut. Kegiatan yang terdapat dalam tahapan pemanfaatan hasil, yaitu terdapatnya pemberdayaan dan penyuluhan yang diberikan dari beberapa pihak terkait kepada masyarakat Jorong Simancuang. Pemberdayan tersebut agar kedepannya dapat berguna bagi masyarakat Jorong Simancuang dalam mengelola hasil hutan. Selanjutnya pada tahapan pemantauan dan evaluasi dengan skor rata-rata 3,5 masyarakat Jorong Simancuang sering terlibat dalam kegiatan pengeloaan hutan nagari, yakni dalam segi menjaga dan melestarikan hutan.

\begin{abstract}
"Pelaksanaan pelatihan untuk hutan sudah banyak dibuat di Jorong Simancuang ini, pelatihan pupuk kompos pelatihan kerajinan, pelatihan patroli dan pelatihan masalah hukum. Waktu pelatihan patroli itu dibantu dari Warsi, sebab kita ini kan didampingi oleh warsi dulunya." (YM, 54 Tahun)
\end{abstract}

Berdasarkan pernyataan responden tersebut, cukup sering ada penyuluhan atau pelatihan yang ada di jorong simcuang, seperti pelatihan pupuk kompos, pelatihan kerajinan dan pelatihan patroli hutan yang dibantu oleh pihak warsi.

\section{Pengaruh Kebijakan Pengelolaan Hutan Desa/Nagari terhadap Tingkat Kesejahteraan Masyarakat Jorong Simancuang}

\section{Tingkat Pendapatan Jorong Simancuang}

Keberadaan hutan nagari telah membuat perbedaan tingkat pendapatan masyarakat Jorong Simancuang pada saat sebelum dan sesudah hadirnya hutan desa. Jumlah pendapatan masyarakat Jorong Simancuang pada saat kondisi sebelum ditetapkannya menjadi hutan desa, dengan pendapatan tertinggi berada pada kategori sedang yaitu lebih dari Rp14.160.624 dan kurang dari $\mathrm{Rp} 23.326 .000$ sebanyak 15 responden atau sebesar 50 persen, sedangkan untuk kategori responden dengan pendapatan tinggi terdapat sebanyak 1 responden atau sebesar 3,3 persen. Hal tersebut disebabkan karena, mayoritas mata pencaharian masyarakat Jorong Simancuang adalah sebagai petani padi dan palawija yang sudah turun-temurun sejak dahulunya, adapun hal ini di karena kondisi akses ketika sebelum ditetapkannya menjadi kawasan hutan desa.

Selain itu, masyarakat Jorong Simancuang juga bergantung dari hasil pertanian secara subsisten dan dijual untuk keperluan lainnya. Adapun perhitungan pendapatan masyarakat Jorong Simancuang ini berdasarkan pendapatan pertahun yang tergolong cukup kecil untuk ukuran pendapatan pertahunnya, yaitu dari 3 kali hasil panen padi dalam jangka waktu 2 tahun. Pada penelitian ini dihitung dalam satu kali panen yaitu pada tahun 2011 saat kondisi sebelum terbentuknya menjadi hutan desa dan pada tahun 2016 saat kondisi setelah terbentuknya menjadi hutan desa. Pendapatan masyarakat pada 5 tahun terakhir ini bergantung dari hasil panen padi sekali dalam setahun, erta hasil panen lainnya seperti cabe, kayu manis, kopi dan karet. Pada saat kondisi hutan simancuang di tetapkan menjadi kawasan hutan desa, terdapatnya pendapatan sebanyak 16 responden atau sebesar 53,3 persen memiliki pendapatan berada pada kategori sedang yaitu lebih dari Rp. 14.160.624 dan kurang dari Rp. 52.876.000. Adapun pendapatan masyarakat Jorong Simancuang yang semakin meningkat dari sebelum ditetapkan menjadi kawasan hutan desa, dilihat dari hasil penelitian pendapatan terendah hanya 7 orang atau 23.3 persen dengan jumlah pengahsilan Rp. 14.160.624 dibandingakan pendapatan petani sebelum ditetetapkannya sebagai kawasan hutan desa yaitu dengan jumlah 14 orang atau 46,7 persen. Setelah hutan Simancuang ditetapkan menjadi kawasan hutan desa, berdampak juga pada tingginya pendapatan masyarakat yaitu, dengan tertinggi adalah Rp. 52.876.000 sebanyak 7 orang 


\section{Tingkat Kondisi Perumahan dan Lingkungan Jorong}

Kondisi perumahan dan lingkungan Jorong Simancuang dilihat dari kondisi sebelum dan sesudah ditetapkannya menjadi hutan desa, adapun yang diketahui bahwa masyarakat Jorong Simancuang ini adalah mayoritas bukan masyarakat asli yang berasal dari Jorong Simancuang, melainkan warga rantauan dan bertempat tinggal di Jorong Simancuang. Pada awalnya masyarakat Jorong Simancuang yang membuka perkampungan baru di Jorong Simancuang hanya dengan kondisi jumlah penduduk yang belum cukup banyak. Namun semenjak bermukim di wilayah Jorong Simancuang, wargapun mulai membuat bangunan tempat tinggal sendiri. kondisi status bangunan tempat tinggal masyarakat Jorong Simancuang, dengan sebelumnya hutan simancuang ditetapkan sebagai hutan desa, masyarakat Jorong Simancuang sudah banyak yang memiliki rumah pribadi yaitu terdapatnya 17 orang (56,7 persen), adapun di saat kawasan hutan simancuang sudah ditetapkan menjadi kawasan hutan desa lebih meningkat lagi dari yang sebelumnya, dengan jumlah responden 26 orang $(86,7$ persen) sudah memiliki rumah peribadi. Hal tersebut terjadi karena, saat masyarakat memulai untuk bermukin di Jorong Simancuang, mayoritas masyarakat sudah membuat bangunan sediri untuk dijadikan tempat tinggal.

Tingkat kesejahteraan kondisi MCK masyarakat Jorong Simancuang saat sebelum dan sesudah ditetapkannya hutan simancuang menjadi kawasan hutan desa, mayoritas masyarakat Jorong Simancuang masih banyak mempergunakan aliran sungai sebagai kebutuhan mandi serta mencuci, hal tersebut dapat dilhat pada jumlah responden sebanyak 27 orang (90 persen) masih mempergunakan aliran air sungai, adapun aliran yang dibawa lansung dari kawasan hutan nagari. Sedangkan pada saat ini setelah ditetapkannya hutan simancuang menjadi kawasan hutan desa, mayoritas masyarakat sudah banyak yang mempergunakan WC sendiri dengan kondisi yang sudah cukup memadai, hal tersebut dilihat dengan terdapatnya 17 orang $(56,7$ persen $)$ masyarakat sudah mempergunakan WC yang cukup baik. Adapun kondisi sumber penerangan yang dipergunakan masyarakat Jorong Simancuang pada saat kondisi sebelum ditetapkan menjadi hutan desa, dengan jumlah 28 orang (93,3 persen) masih mempergunakan lilin atau lampu teplok. Sedangkan, dibandingkan dengan kondisi sesudah ditetepkannya menjadi kawasan hutan desa, menunjukkan 30 orang (100 persen) sudah mempergunkan listrik dari PLN. Sedangkan, kondisi jenis dinding warga Jorong Simancuang, dengan sebanyak 30 orang (100 persen) sebelum hutan simancuang dijadikan sebagai kawasan hutan desa masih mempergunakan dinding yang terbuat dari kayu. Hal tersebut terjadi karena, saat masyarakat Jorong Simancuang baru pertama kali bermukim di wilayah Jorong Simancuang dengan membangun rumah, warga hanya mempergunakan kayu dari hutan untuk bangunan rumah. Namun saat ini, dengan sudah ditetapkannya hutan simancuang menjadi kawasan hutan desa, sudah terdapatnya perubahan pada masyarakat dengan membuat bangunan baru disamping lahan rumahnya dengan bangunan bertembok bata atau beton, hal tersebut dilihat dengan jumlah 4 orang (13,3 persen) responden masyarakat Jorong Simancuang sudah mempergunakan bangunan dari tembok bata atau beton.

Pada kondisi lantai rumah, di saat hutan simancuang sudah ditetapkan menjadi hutan desa, banyak masyarakat mulai merubah bangunan rumah mereka dengan bangunan permanen dengan lantai yang beralaskan keramik atau ubin. Hal tersebut dilihat dengan terdapatnya 5 orang (16,7 persen) masyarakat Jorong Simancuang yang sudah mempergunakan keramik atau ubin sebagai alas lantainya. Selain itu kondisi MCK saat sesudah hutan simancuang ditetapkan menjadi hutan nagari, terdapat 22 orang $(73,3$ persen) responden telah mempergunakan fasilitas MCK milik sendiri. Hal tersebut terjadi karena, mulai banyaknya kunjungan dari orang luar untuk meneliti, serta melihat kondisi hutan nagari, dan terdapatnya beberapa rumah masyarakat yang dipergunakan sebagai tempat tinggal, serta membuat masyarakat mulai ikut mempergunakan fasilitas MCK sendiri. 


\section{Pengaruh Kebijakan Perhutanan Sosial terhadap Tingkat Partisipasi Masyarakat dalam Pengelolaan Hutan}

Terdapatnya kebijakan akses masyarakat dalam mengelola hutan nagari memiliki hubungan juga dengan sudah dibuatnya perencana pengelolaan hutan nagari sesuai aturan yang telah di tetapkan. Melalui peraturan tersebut, membuat masyarakat lebih terorganisir dalam mengelola hutan. Pada perencanaan pengelolaan hutan nagari tersebut, terdapatnya berbagai kegiatan yang melibatkan masyarakat Jorong Simancuang. Adapun kegiatan tersebut dapat berguna bagi masyarakat Jorong Simancuang yakni dari segi sosial, lingkungan dan perekonomian masyarakat. Kegiatan pengelolaan hutan nagari ini bertumpu pada LPHN. Dengan berlansungnya berbagai kegiatan dan pelatihan dari berbagai pihak seperti KKI Warsi, LSM, dan Pemerintah yang diberikan kepada masyarakat menimbulkan perkembangan pada kreatifitas masyarkat Jorong Simancuang yang dapat bermanfaat bagi kehidupannya. Kegiatan tersebut penunjang untuk membantu masyarakat Jorong Simancuang lebih berkembang lagi dengan pelatihan dan penyuluhan dalam mengelola hasil hutan ataupun usaha hasil pertanian. Selain itu, Jorong Simancuang mulai didatangi oleh orang-orang luar hanya untuk sekedar berkunjung ataupun penelitian dan menjadi peluang besar bagi masyarakat Jorong Simancuang untuk dapat lebih dikenal, sehingga masayarakat Jorong Simancuang mulai diperhatikan. Adapun dengan menerima sebagai wana lestari dari Kementerian Kehutanan tahun 2016 atas peran aktif masyarakat Jorong Simancuang dalam pengelolaan hutan nagari memperlihatkan bahwa peran masyarakat saat ini dalam melakukan pembangunan dengan adanya pengelolaan hutan nagari ini sudah sangat baik. Selain itu, berpengaruh juga secara luas bagi masyarakat Jorong Simancuang yakni dengan mulainya masuk listrik dan fasilitas akses jalan yang sudah bisa dilewati. Oleh sebab itu, dengan keberadaan hutan nagari simancuang memiliki peran penting bagi kehidupan masyarakat Jorong Simancuang, yaitu dapat memberikan perubahan dalam kehidupan masyarakat Jorong Simancuang.

\section{Pengaruh Tingkat Partisipasi Dalam Kebijakan Pengelolaan Hutan Nagari terhadap Tingkat Kesejahteraan Masyarakat}

\section{Pengaruh Tingkat Partisipasi dalam Pengelolaan Hutan Nagari terhadap Tingkat Pendapatan Mayarakat Jorong Simancuang}

Tingkat partisispasi masyarakat Jorong Simancuang dalam pengelolaan hutan nagari dilihat dalam indikator partisiapsi masyarakat yakni pada tahapan perencanaan kegiatan, tahap pelaksanaan kegiatan, tahap pemanfaatan hasil serta tahap pemantauan dan evaluasi. Melalui tahapan partisipasi tersebut dalam program ataupun kegiatan yang terdapat pada pengelolaan hutan nagari, apa bila memberikaan pengaruh sedang, maka selisih pendapatan masyarakat Jorong Simancuang di atas 25 persen sampai dengan dibawah 75 persen, terdapat 9 orang.

Pada saat partisipasi masyarakat dalam pengelolaan hutan nagari tersebut rendah, maka selisih pendapatan masyarakat Jorong Simancuang dibawah 25 persen terdapat 2 orang. Sedangkan partisipasi masyarakat dalam pengelolaan hutan nagari tinggi, maka selisih pendapatan masyarakat di atas 25 persen sampai dengan dibawah 75 persen, terdapat 5 orang. Hal tersebut sudah mulai terdapatnya pengaruh dari partisipasi masyarakat Jorong Simancuang dalam pengelolaan hutan nagari sudah mulai menimbulkan perubahan pada pendapatan masyarakat, yakni dilihat dari semenjak masyarakat Jorong Simancuang berpartisipasi dalam pengelolaan hutan nagari, banyak pelatihan serta ilmu yang didapatkan dalam kegiatan pengelolaan hutan nagari.

Tabel 3 Jumlah responden berdasarkan pengaruh tingkat partisipasi dalam pengelolaan hutan nagari terhadap selisih pendapatan masyarakat Jorong Simancuang

$\begin{array}{cc}\text { Pendapatan } & \text { Partisipasi dalam pengelolaan } \\ \text { masyarakat } & \text { Hutan Nagari }\end{array}$




\begin{tabular}{|c|c|c|c|c|}
\hline Jorong & Renda & Sedan & Tingg & $\begin{array}{c}\text { Jumla } \\
\mathrm{h}\end{array}$ \\
\hline Simancuang & $\mathrm{h}$ & $\mathrm{g}$ & $\mathrm{i}$ & $\mathrm{h}$ \\
\hline$<25 \%$ & 2 & 4 & 1 & 7 \\
\hline $\begin{array}{l}25 \%<X<75 \\
\%\end{array}$ & 2 & 9 & 5 & 16 \\
\hline$<75 \%$ & 3 & 4 & 0 & 7 \\
\hline
\end{tabular}

Oleh sebab itu, melalu kegiatan tersebut terdapatnya pelatihan dalam keterampilan dan membuahkan hasil untuk dapat dijual.Namu hal tersebut belum berjalan dengan lancar dalam pemanfaatn hasil hutan yakni dengan membuat kterampilan, tetapi dari segi lain masyarakat Jorong Simancuang sudah mulai dapat beberapa penyuluhan dan bantuan bibit pertanian yakni untuk menambah penghasil pertanian bagi masyarakat Jorong Simancuang. Selain itu dari segi akses juga memiliki peran dalam peningkatan pendapatan masyarakat Jorong Simancuang dalam skala harga penjualan hasil pertanian.

\section{Pengaruh Tingkat Partisipasi dalam Pengelolaan Hutan Nagari terhadap Kondisi Rumah dan Lingkungan Mayarakat Jorong Simancuang}

Terdapatnya pengaruh partisipasi masyarakat Jorong Simancuang dalam pengelolaan hutan nagari terhadap kondisi rumah dan lingkungan masyarakat Jorong Simancuang sesudah ditetapkan hutan nagari. Adapun partisipasi masyarakat dalam pengelolaan hutan nagari rendah, maka kondisi rumah dan lingkungan masyarakat Jorong Simancuang saat sudah ditetapkan menjadi kawasan hutan nagari dengan kondisi rendah terdapat 2 orang. Apabila partisipasi masyarakat dalam pengelolaan hutan nagari sedang, maka berpengaruh terhadap kondisi rumah dan lingkungan sesudah ditetapkan menjadi kawasan hutan nagari sedang, terdapat 9 orang. Sedangkat partisipasi masyarakat dalam pengelolaan hutan nagari tinggi, maka berpengaruh tinggi pada kondisi rumah dan lingkunga sesudah ditetapkan hutan nagari terdapat 1 orang.

Tabel 4 Jumlah responden berdasarkan pengaruh tingkat pasrtisipasi dalam pengelolaan hutan nagari terhadap kondisi rumah dan lingkungan sesudah ditetapkan hutan desa

\begin{tabular}{|c|c|c|c|c|}
\hline \multirow{2}{*}{$\begin{array}{c}\text { Kondisi } \\
\text { Rumah dan } \\
\text { Lingkungan } \\
\text { Sesudah } \\
\text { ditetapkan } \\
\text { Hutan Nagari }\end{array}$} & \multicolumn{4}{|c|}{$\begin{array}{c}\text { Partisipasi dalam pengelolaan Hutan } \\
\text { Nagari }\end{array}$} \\
\hline & Rendah & Sedang & Tinggi & Jumlah \\
\hline Rendah & 2 & 5 & 0 & 7 \\
\hline Sedang & 4 & 9 & 4 & 17 \\
\hline Tinggi & 1 & 4 & 1 & 6 \\
\hline
\end{tabular}

Adapun hal tersebut dengan kondisi rumah dan lingkungan pada saat sesudah ditetapkannya kawasan hutan desa berada pada kondisi sedang atau biasa saja. Hal tersebut dengan tidak terlalu terlihat dampak perubahan besar saat sesudah ditetapkannya kawasan hutan nagari. namun hal tersebut, memliki cukup berpengaruh dengan besarnya partispasi masyarakat dalam pengelolaan hutan nagari dapat menimbulkan kepedulian masyarakat akan pada lingkungan disekitar rumahnya. Dengan di lihat dari kondisi MCK masyarakat, sebelumnya di tetapkan kawasan hutan nagari, mayoritas hampir semua masyarakat Jorong Simancuang mempegunakan sungai sebagai tempat pembuangan air besar ataupun kecil hingga mencuci dan mandi. Namun sekarang sudah mulai banyak perubahan terjadi. Masyarakat Jorong Simancuang sudah mulai akan peduli terhadap lingkungan dengan mulai pada memeliki fasilitas MCK dan kamar mandi sendiri. Namun kondisi tersebut belum tampak begitu merata keseluruh masyarakat Jorong Simancuang. Adapun informasi menurut dari salah satu informan.

\footnotetext{
"Dulu kami ini kalau mau mandi, mencucui dan kalau mau buang air besar harus ke sungailah, kemana lagi. WC belum punya lagi. Tapi waktu orang-orang yang sering datang kesini itu kami belum ada WC lagi, lalu mereka membantu dengan membuatkan kamar mandi serta tempat pembuangan air besar dirumah ini. Kalau sekarang kami sudah bisa mandi dikamar mandi sendiri lagi, mencucipun terkadang masih ada juga la pergi kesungai, tapi setidaknya kalau mau membuang air besar dan mandi sudah di kamar mandiu sendiri." (MY,56 Tahun)
}

Berdasarkan informasi dari responden tersebut, semenjak banyaknya tamu atau orang - orang yang datang berkunjung ke Jorong Simancuang untuk melihat atau meneliti di hutan nagari, mulailah banyak bantuan serta penyuluhan akan 
pentingnya memiliki fasilitas WC yang bersih. Oleh sebab itu mulai banyak masyarakat Jorong Simancuang yang mulai memilki fasiltas kamar mandi sendiri serta dengan kondisi MCK yang cukup baik. Selain itu, kondisi rumah masyarakat Jorong Simancuang mayoritas memilki rumah semi permanen, yakni masih banyak yang beralaskan semen dan dinding yang terbuat dari kayu. Tetapi saat ini sudah mulai banyak dari beberapa masyarakat yang mulai berkembangan dengan mengubah bangunan rumahnya dengan membangun disamping rumah dengan kondisi rumah yang beralaskan kerami dan tembok beton. Oleh sebab itu, hal ini sudah mulai terlihat adanya pengaruh dari partisipasi masyarakat dalam pengelolaan hutan nagari terhadap kondisi rumah dan lingkungan masyarakat sesudah ditetapkan hutan nagari.

\section{SIMPULAN DAN SARAN}

\section{Simpulan}

Skripsi ini dilakukan dengan berpandu pada dua hipotesis. Hipotesis pertama, kebijakan perhutanan sosial (khususnya hutan desa) telah menjadi pendorong meningkatnya partisipasi masyarakat dalam pengelolaan hutan nagari Jorong Simancuang. Hipotesis ke dua, tingkat pendapatan dan kualitas perumahan dan lingkungan warga meningkat sebagai akibat meningkatnya partisipasi masyarakat dalam pengelolaan hutan nagari Jorong Simancuang. Berikut adalah fakta-fakta ilmiah yang diperoleh terkait dengan hipotesis tersebut.

1. Kebijakan Perhutanan Sosial telah meningkatkan partisipasi dalam pengelolaan hutan nagari Jorong Simancuang. Hal ini ditunjukkan oleh tingkat partisipasi warga yang tergolong sedang hingga tinggi pada tahap perencanaan (skor 3,75), pelaksanaan (skor 3,73), pemanfaatan (skor 3,95), dan pemantauan serta evaluasi (skor3,5); dengan skor maksimum 5 (partisipasi masyarakat sangat tinggi) (lihat pada Tabel 12). Tingkat partisipasi yang tergolong tinggi dibandingkan yang lain adalah pada tahapan pemanfaatan hasil kegiatan. Sementara tingkat partisipasi yang paling rendah dijumpai pada tahapan pemantauan dan evaluasi kegiatan. Adapun tingginya partisipasi pada tahap pemanfaatan hasil disebabkan karena tingginya keikutsertaan anggota PS hutan lindung nagari Jorong Simancuang pada kegiatan pemberdayaan dan pelatihan dalam pemanfaatan hasil hutan. Kebijakan Perhutanan Sosial yang telah membuka ruang akses warga Jorong Simancuang untuk melindungi dan mengelola Hutan Lindung Simancuang sebagai penunjang kehidupan mereka.

2. Penetapan kawasan hutan lindung nagari Jorong Simancuang yang dikelola dengan skim Perhutanan Sosial (Hutan Desa, HD); tidak hanya meningkatkan partisipasi warga tetapi juga berpengaruh positif terhadap tingkat kesejahteraan warga nagari dan kondisi rumah dan lingkungan hidup nagari Jorong Simancuang. Hasil studi menunjukkan bahwa setelah dikukuhkan sebagai Hutan Desa pendapatan warga Jorong Simancuang menunjukkan peningkatan. Sebelum ditetapkan sebagai $\mathrm{HD}$, persentase rumah tangga responden hutan nagari Jorong Simancuang yang memiliki pendapatan $>\mathrm{Rp}$ 52.876 .000 per tahun hanya 3,3 persen. Kini setelah ditetapkan sebagai HD, persentase rumah tangga responden hutan nagari Jorong Simancuang yang pendapatannya $>\mathrm{Rp}$ 52.876.000 per tahun mencapai 23,3 persen.

3. Dalam hal perbaikan kondisi rumah diperoleh fakta bahwa setelah ditetapkan sebagai HD: (i) sekitar 56,7 persen rumah responden telah memiliki fasilitas WC sendiri (sebelum HD, 90 persen rumah responden menggunakan sungai untuk keperluan MCK); (ii) 100 persen rumah responden menggunakan listrik (sebelum HD, 93,3 persen responden menggunakan lilin/lampu teplok); (iii) 100 persen rumah responden kini berdinding bata (sebelum HD, 13,3 persen berdinding bata); (iv) 16,7 persen rumah responden berlantai keramik (sebelum HD, 100 persen rumah responden berlantai kayu).

4. Berdasarkan fakta ilmiah yang telah diutarakan di atas dapat disimpulkan bahwa kebijakan Perhutanan Sosial, dalam hal ini penetapan Hutan Desa Nagari Jorong Simancuang telah mendorong partisipasi masyarakat dalam melindungi, mengelola dan 
memanfaatkan Hutan Lindung Simancuang; dan telah meningkatkan kesejahteraan warga Nagari Jorong Simancuang, khususnya dalam hal pendapatan, kondisi fisik rumah responden, dan kondisi lingkungan sekitar.

\section{Saran}

Adapun saran yang dapat diberikan merujuk hasil penelitian ini adalah sebagai berikut.

1. Akademisi dan Lembaga pengelolaan hutan nagari perlu meningkatkan kualitas sumberdaya manusia (SDM) dalam mengelola hutan nagari, agar dapat meningkatkan kemampuan masyarakat dalam mengelola hasil hutan dan pertanian dengan baik.

2. Pemerintah perlu memberikan pelatihan keterampilan pemasaran kepada petani sehingga petani dapat mengembangkan pekerjaannya tidak hanya sebatas budidaya pertanian tetapi juga dapat mengelolaah hasil pertanian dan hasil hutan untuk menjadi nilai tambahan pemasukan bagi masyarakat Jorong Simancuang.

3. Masyarakat Jorong Simancuang perlu dipertahankan ke aktifannya dalam mengikuti kegiatan pengelolaan hutan nagari, namun mesti ditingkatkan lagi dalam keterampilan mengelolaa hasil hutan dan hasil pertanian untuk dapat membantu meningkatkan perekonomian masyarakat.

\section{DAFTAR PUSTAKA}

[BPS] Badan Pusat Statistik. 2000. Sensus Pertanian Indonesia. Jakarta: BPS.

[BPS] Badan Pusat Statistik. 2008. Analisis dan Penghitungan Tingkat Kemiskinan. Jakarta: BPS.

[BPS] Badan Pusat Statistik. 2010. Hasil Pencacahan Survei Kehutanan Rakyat Tahun 2010.

[UU] Undang-Undang Nomor 41 Tahun 1999 tentang Kehutanan

[UU] Undang-Undang Republik Indonesia Nomor 11 Tahun 2009 pasal 1 tentang Kesejahteraan Sosial
[Kemenhut] Kementerian Kehutanan Nomor 88 tahun 2014 tentang Hutan Kemasyarakatan

[Kemenhut] Kementerian Kehutanan Nomor 89 tahun 2014 tentang Hutan Desa

[Kemenhut] Kementerian Kehutanan Direktural Jendral Perhutanan Sosial dan Kemitraan Lingkungn Nomor: P.11/PSKL/SET/PSL.0/11/2016 tentang pedoman verivikasi permohonan Hak Pengelolaan Hutan Desa (HPHD)

[Permenhut] Peraturan Menteri Kehutanan Nomor P.49/Menhut-II/2008 tentang Hutan Desa

[Permenhut] Peraturan Menteri LHK No. P.83/MENLHK/SETJEN/KUM.1/10/20 16 tentang Perhutanan Sosial

Kartasubrata, J. 2000. Partisipasi Rakyat dalam Pengelola dan Pemanfaatan Hutan di Jawa. Disertasi. Bogor: Program Pascasarjana, Insitut Pertanian Bogor

Ngabdi M, Muryani C, Sudaryanto R. Partisipasi Masyarakat dalam Pelaksanaan Program Pengelolaan Hutan Bersama Masyarakat (PHBM) di Desa Girimulyo Kecamatan Jogorogo Kabupaten Ngawi. Jurnal GeoEco [Internet]. 1 (1). [Diunduh tanggal 3 Maret 2017]. Tersedia pada http://jurnal.fkip.uns.ac.id/index.php/geo eco/article/view/5975

Ostrom, E. 1990. Governing The Commons. The Evolution of Institutions for Collective Action. Cambridge University Press.

Sutejo P. Hubungan Program Pengelolaan Hutan Bersama Masyarakat Terhadap Peningkatan Pendapatan Rumah Tangga. Jurnal Ilmiah Pendidikan Geografi. 2 (1). [Diunduh tanggal 12 Oktober 2016].

Tukiran, Effendi. 2014. Metode Penelitian Survei. Edisi Revisi. Jakarta (ID):LP3ES

Waliulu AR. Bentuk-Bentuk Partisipasi Masyarakat Sekitar Hutan terhadap Keamanan Hutan. Jurnal Pertanian Mapeta [Internet]. 4 (13). [Diunduh Tanggal 3 Maret 2017]. Tersedia Pada 
Zulevi \& Adiwibowo / JSKPM 2(1): 13-28

ournal.uny.ac.id/index.php/natapraja/arti cle/download/3463/2945 